\title{
特別講演会
}

\section{「日本家畜臨床学会 特別講演2011」に参加して}

\author{
山口 猛
}

\author{
NOSAI宮城 県南家畜診療センター
}

平成23年 9 月 8 日, ホテルメトロポリタン仙台にて日 本家畜臨床学会特別講演が開催された。講師に英国ス ウォンジー大学教授のマーティン・シェルドン先生をお 招きし，乳牛の子宮疾患についてご講演いただいた。 以 前からシェルドン先生の論文を帱見していたが, それら の内容はもちろんのこと, 今回新たに耳にする知見も あって大変興味深い内容であった。

講演内容は大きく分けて 4つのテーマからなり, (1)正 常な産裖期, (2)子宮の感染と疾患, (3)子宮の免疫機構,

(4)子宮疾患が卵巣に及ぼす影響について, それぞれ写真 やイラストを交えながらわかりやすく解説していただい た。

子宮は常に分婏に伴う不顕性細菌感染と自発的な細菌 排泄とを繰り返しており, 子宮疾患の発生は感染と免疫 のバランスの上に成り立っているといえる，子宮疾患の なかでも子宮内膜炎は繁殖成績に与える影響が大きい. 子宮内膜炎が治癒したとしても, 分婏から初回授精まで の日数および分婏から受胎までの日数は延長するといわ れている. 子宮内膜炎のリスクファクターとしてさまざ まなものがあげられるが, とくに重要なものは胎盤停 滞，死産および助産である。これらのリスクを回避する 方法として，難産を防ぐことなどが挙げられる.
大腸菌はもっとも一般的な子宮内細菌の一つである. EnPECとよばれるある特定の大腸菌株は牛の子宮内膜 に対する病原性が高く，炎症性疾患の原因になるといわ れている. EnPECは正常子宮から検出される大腸菌に 比べて子宮内膜間質に対する接着性が高いことが分かっ ており, 分娩直後で上皮のはがれた状態の子宮内膜に接 着しやすい性質を有している。今回初めてEnPECとい うものの存在を知り, 非常に関心を持った。 ウイルスも また子宮疾患に関与していることが知られており，特に 牛ヘルペスウイルス 4 型は子宮内膜に向性であるため, 主要な原因ウイルスとされている。宮内膜炎をはじめ とする子宮疾患に対し，臨床的な視点からだけでなく， さまざまな角度からアプローチがなされていて, 改めて 子宮疾患の奥深さを実感することができた。また通訳に ご協力いただいた酪農学園大学教授の片桐成二先生にわ かりやすくご説明いただき，内容をよく理解することが できた。今回学んだことを日々の診療に活かしていきた いと思う.

最後に, 今回の講演を主催してくださった日本家畜臨 床学会ならびに協賛いただいたファイザー株式会社に感 謝申し上げたい. 